\title{
市民参画型の里山管理における作業効率把握に関する 研究
}

\author{
Study on Estimation of Management Efficiency in Preserving Satoyama Conducted by Local Residents
}

谷㠃 聡史*・加我 宏之**・下村 泰彦**・増田＼cjkstart昇**

Satoshi TANIZAKI Hiroyuki KAGA Yasuhiko SHIMOMURA Noboru MASUDA

\begin{abstract}
Recently, Japan has seen the trend throughout the nation that management activities for preserving Satoyama have been more voluntarily conducted by local residents. The management activities ranged from region to region, depending on the levels of management skill local residents acquired, which have made it difficult for researchers to predict how effective management activities, including thinning and forest floor management, are in preserving Satoyama. This study was conducted to estimate the management efficiency in preserving Satoyama in Osaka Prefecture through a field survey. The field survey was carried out at 21 different areas, and the interview was conducted on 6 different groups of local residents who voluntarily participated in management activities. The results obtained were: 1) management efficiency played a big difference between the initial management, such as thinning and creating square, and the regular management such as weed clearing; 2) As for manual labor, management efficiency was 4.2 persons $/ 100 \mathrm{~m}^{2}$ /day in the initial management when thinning was only conducted monthly by the operating officials. Management efficiency was 2.8 persons $/ 100 \mathrm{~m}^{2} /$ day in the regular management activities excluding weed clearing, which was conducted monthly by the operating officials; 3) As for machine use, management efficiency almost doubled when compared with those with manual labor. Management efficiency was 2.0 persons $/ 100 \mathrm{~m}^{2} /$ day in the initial management, and 1.8 persons $/ 100 \mathrm{~m}^{2} /$ day in the regular management.
\end{abstract}

Keywords: preserving Satoyama, Satoyama management, management efficiency, public involvement キーワード：里山保全, 里山管理, 作業効率, 市民参画

\section{1.はじめに}

1980 年代後半になると，放置された里山を市民の手で管理す る里山づくりが全国各地で活発に行われるようになり，里山の保 全・活用の方向性を多様な側面から検討することの必要性 ${ }^{1)}$ と むに, 里山管理計画を実行へ移すプロセスの重要性が認識され始 めた。市民活動で里山を管理していく場合, 今後の管理活動を企 画立案していくためには, 参加者がある一定期間において, どれ だけの規模の面積を管理することが可能と考えられるのかを把握 することが不可欠だと考えられる。中川22 によると里山管理にお ける労働力と管理規模のバランスを見極めることや, 植生管理本 来の目的とそれを達成するために必要な具体的な労働力を明確に することが必要としている。

里山管理における管理規模と労働力との関連性について報告し た事例としては, 重松3) は市民ボランティアによるササ刈り・密 生低木の下刚り ・選択的下刈り・間伐といった管理作業において, 1 日の基本的な夕イム・スケジュールを設定し, 参加者の年齢構 成之 1 人当たり平均作業率を明らかにしている。また，高橋 $\left.{ }^{4}\right)$ あ選択的下刚りに扔いて, 手で刈った場合と機械を使用した場合 の作業量を算出している。このように, 里山管理においては参加 者の作業量と管理規模のバランスを定量的に測定する必要性が論 議され, 測定したデータが報告されているが, デー夕量が少ない ことや，管理活動の目的や活動場所の状況といった要因が考慮さ れていないこと，これまで市民参画で行われた里山管理の結果を まとめた事例が少ないなどの課題む残されている。

本研究では, 大阪府下で市民が中心となって実践的に里山管理 活動を行っている 6 団体を対象に, 活動参加者へのヒアリング調 查を通じて里山管理に㧍ける目的別の作業効率を把握するととも
に，現地調查を通じて活動場所の植生状況を把握することによっ て, 今後の市民参画型の里山管理活動における参加者の作業量之 管理規模のバランスに対する基礎的知見を得ることを試みた。

\section{2. 研究の方法}

\section{（1）調査対象地の抽出と植生状況の調査方法}

本研究では，まず対象とする団体を選定するために，大阪府下 で，里山保全活動を実施していると考えられる市民団体に対して アンケート調査を実施した。アンケート調査の対象となる団体は, 大阪府下の各市町村が把握している自然保護系市民活動団体,

（社）大阪みどりのトラスト協会が作成した大阪府下自然系 NPO 法人・ボランティア団体一覧表, （財）日本自然保護協会里山保 全活動リストから抽出した 82 団体である。団体へのアンケート 調査票の送付は平成 15 年 6 月 24 日に郵送回収方式で実施し, 38 団体の有効回答（46.3\%）を得た。

アンケートの設問は, 市民団体の里山管理に対する志向性と活 動内容, 活動場所に関して回答を求めるとともに詳細調査への協 力意向からなる。アンケート調査結果より, 市民参画型で里山管 理を行っている団体の中から，「林床管理」や「樹木管理」等の 実活動を行っている団体で, かっ, その活動場所が市街地縁辺部 のかつて里山として利用されていた場所で竹林や人工林を除く雑 木林である団体の中から, 詳細調查の協力を得られた 6 団体を抽 出した。

具体的には，池田市で活動している「五月山グリーンェコー」, 交野市で活動している「交野里山ゆうゆう会」, 箕面市で活動し ている「ありもりクラブ」と「外院の森」, 南河内郡河南町で活 動している「里山俱楽部」, 泉南市で活動している「泉南の里山

*神戸市建設局公園砂防部 ${ }^{* *}$ 大阪府立大学大学院農学生命科学研究科 
を大切にする会」を調查対象団体とし て抽出し，この 6 団体の活動場所から 雑木林 21 地点を抽出した。

な抢，五月山グリーンェコーは， 「身近な自然環境である五月山を，生 き物が豊かで明るくイキイキとした森 に回復させ，その森を市民誰もが気楽 に安心して自然と楽しめる, そんな里 山自然公園にしていく」ことを目的と して, 1996 年から管理活動を行って いる団体で, 現在の会員数は約 127 名 である。活動内容は間伐や下草刈り等 の管理作業を中心に，竹炭や竹工作， 自然観察会, 小学生の環境学習の指導 など屯行っている。なお，イベントを 除く定例的な里山管理作業の参加者を, 里山管理活動の経験年数や林業等への 従事経験, 里山講座の受講歴等から作 業能力の違いによって上級者・中級者・ 初心者に分類した場合, その割合はお

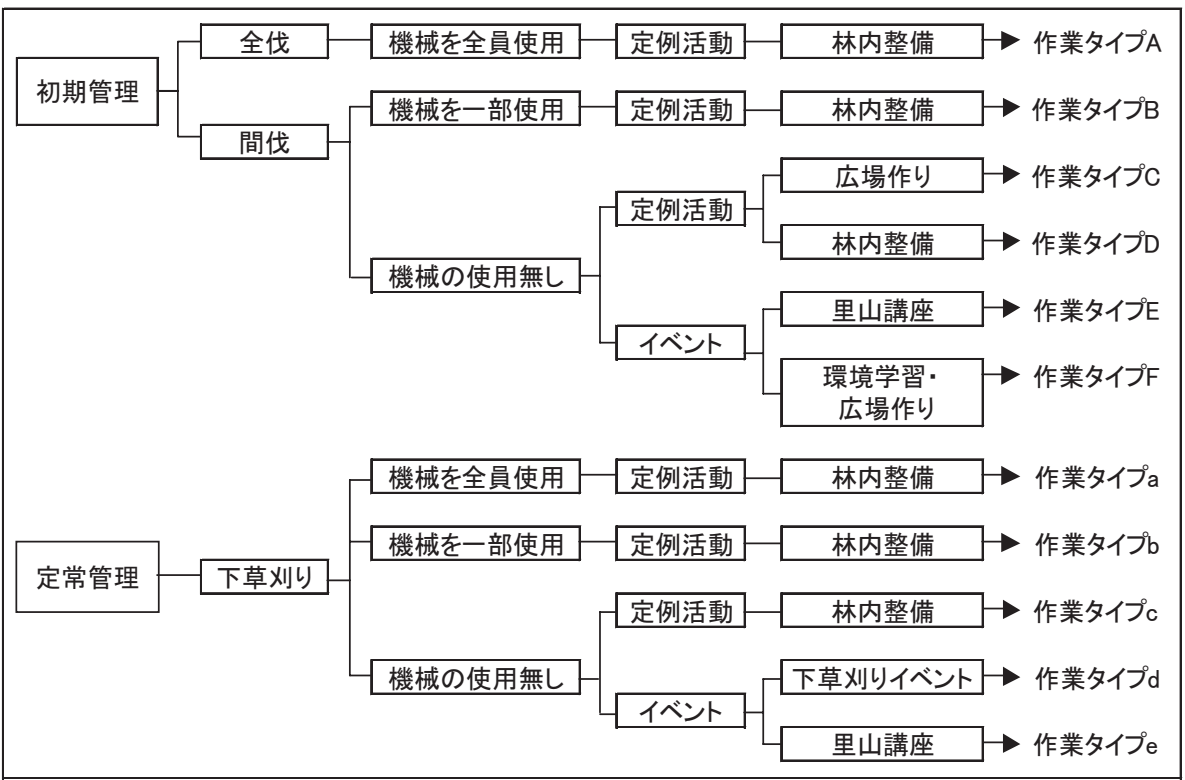

よそ6：4：0であった。

交野里山ゆうゅう会は, 2001 年に大阪府交野市の広大な山林 を保全する市民を養成することを目的とした「里山育成指導員講 座」の講座修了生 25 名によって発足した団体で, 現在の会員数 は70名であり, 現在は間伐や下草刈り, 竹林の除伐, 植林以外 に植物観察会, 名札付け, 体験学習などを行っている。なお, イ ベントを除く定例的な里山管理作業の参加者を, 上記と同じ上級 者・中級者・初心者に分類した場合, その割合は抢上そ $3 ： 7 ：$ 0 であった。

外院の森は, 大阪府箕面市の快適環境づくり計画に掲げられて いる「学校の杜」構想モデル事業として 1999 年に会員数 30 名で 発足し, 現在の会員数は約 130 名であり, 自然体験や環境学習が できる森を小学校区単位でっくっていくことを目的とし, 子供か ら大人までが自然に親しみ, 自然から学び, そして自然の維持管 理に係わる場として整備を行っている。活動内容は広場作りを目 的とした間伐を行っている他, 小学生の環境学習の指導を積極的 に行っている。なお, イベントを除く定例的な里山管理作業の参 加者を, 上記と同じ上級者・中級者・初心者に分類した場合, そ の割合は打よそ1：6：3であった。

ありありクラブは, 1994 年に大阪府箕面市が実施したもりづ くり実習講座の受講者を中心に 1995 年に発足した団体で, 現在 は会員数約 105 名で「市民による森づくりが森を守る」をテーマ に活動を行っている。活動内容は間伐や下草刈りを中心に, 炭焼 き, 小鳥の巣箱づくり, カブトムシの増殖, 杉林の手入れ, シイ 夕ケ栽培などを行っている。なお, イベントを除く定例的な里山 管理作業の参加者を, 上記と同じ上級者・中級者・初心者に分類 した場合，その割合は㧍よそ3：1：6であった。

里山俱楽部は, 1994 年に大阪府の河南町を活動の中心として いる市民団体である「南河内水之緑の会」の中で里山保全活動を 専門で行う部会として「里山俱楽部」が設けられ, 活動が開始し た団体である。「好きなことして，そこそこ儲けて，いい里山を みんなで作ろう」を合言葉とし, 里山保全活動を行っており, 2000 年には NPO 法人を取得し, 周辺の自治体から里山をめぐる 環境教育やまちづくりなどの事業を受託し, 運営資金を確保して いる。里山の育成方針として 1996 年から全伐方式を採用し, 皆 伐した後にはクヌギの苗木を植樹している。なお，イベントを除 く定例的な里山管理作業の参加者を，上記と同じ上級者・中級者・ 初心者に分類した場合, その割合は抢よそ4：3：3であった。

泉南の里山を大切にする会は, 2000 年 4 月に有志によって設 立された大阪府泉南市で活動する市民団体である。「地球環境を 守るため泉南の里山の整備・保全・活用を行う」を活動目的とし, 活動内容は間伐や下草刈りに加えて, 自然観察会, 環境学習の指 導，シイタケ栽培などを行っている。なお，イベントを除く定例 的な里山管理作業の参加者を, 上記と同じ上級者・中級者・初心 者に分類した場合，その割合は抢よそ0：4：6であった。

また調查対象地の植生状況を把握するために, 21 地点それぞ れの中で平均的な箇所を活動地面積の大きさに応じて $1 \sim 4$ 箇所 をサンプリングし, その平均をとる方法で, 平成 15 年 7 月から 9 月にかけて, 1 箇所につき $10 \times 10 \mathrm{~m}$ の調査区を設定し, 植生状 況として林相, 高木 ・ 亜高木の立木密度, 低木の立木密度, 林床 被度について現地調査を行った。なお，この植生状況は現況の屯 ので，管理活動が実施された後の状況である。

\section{（2）ヒアリング調査}

各団体の里山管理における作業量を把握するために, ヒアリン グ調査を平成 15 年 9 月上旬から平成 15 年 10 月下旬にかけて, 各団体の代表者屯しくは事務局担当, 行政の担当者に直接面談方 式で実施した。ヒアリング回数は各団体に対して 1 回約 2 時間で 平均 4 回行い, 活動日誌を基にヒアリングするとともに各団体の 実施する里山管理活動に参加しながら調査を行った。

ヒアリング調查項目は, 活動場所の位置, 活動目的, 調查対象 地点での活動回数, 各回ごとの活動人数と作業方法（作業に用い た器具等）である。なお，活動場所の面積之傾斜度はヒアリング 調查によって確認した活動場所を 2500 分の 1 の地形図に転写し, プラニメーター等を用いて测定した。

\section{（3）作業効率の算定方法}

里山管理における作業効率の算定方法は，ヒアリング調査によっ て得た活動面積に対して活動に参加した総人数と, 1 回当りの平 均活動時間のデー夕を用いて, 1 日の活動時間を 4 時間に設定し, 1 日に面積 $100 \mathrm{~m}^{2}$ を管理するのに必要な人数, すなわち単位面積 当りの日人数として算定した。

な㧍，算定に際して，里山管理活動は皆伐や間伐（除伐，択伐 あ含む）などの初期管理と, 初期管理が実行された後の下草刈り の定常管理では, その作業内容が大きくことになることから, 初 期管理と定常管理に分けて算定するものとした。 
表-1 作業タイプごとの作業効率

\begin{tabular}{|c|c|c|c|c|c|c|c|c|c|c|}
\hline & 作業タイプ & $\begin{array}{l}\text { 作業 } \\
\text { 内容 } \\
\end{array}$ & & 機械の使用 & & の目的 & 活動場所 & $\begin{array}{l}\begin{array}{l}\text { 平均傾斜 } \\
\text { (度) }\end{array} \\
\end{array}$ & 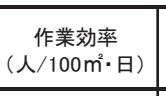 & $\begin{array}{c}\text { 作業効率の } \\
\text { 平均值 } \\
\left(\mathcal{1} / 100 \mathrm{~m}^{2} \text {-日 }\right) \\
\end{array}$ \\
\hline & 作業タイプA & 皆伐 & 全員使用 & チェーンソウ·草刚り機 & 定例活動 & 林内整備 & 里山A & 32 & 2.2 & 2.2 \\
\hline & & & & & & & 五月山A & 23 & 1.6 & \\
\hline & 作業タイプB & 間伐 & 使用 & ノギリ・ナタ・チェーンソウ(1台) & 定例活動 & 林内整備 & 五月山B & 9 & 1.3 & 2.0 \\
\hline & & & & & & & 交野A & 24 & 3.0 & \\
\hline & 作對タイプC & 闁代 & 無 & ノギリ & 定例活動 & 庆場作り & 外院B & 6 & 11.2 & 1071 \\
\hline & TF未メン & (1日9) & & ・コキリ & 定例活野 & 仏场作り & 外院C & 13 & 10.3 & 10.7 \\
\hline 初 & & & & & & & 泉南A & 20 & 3.2 & \\
\hline 期 & & & & & & & 泉南B & 22 & 3.0 & \\
\hline 管 & & & & & & & 外院 & 25 & 5.3 & \\
\hline 理 & 作業タイプD & 間伐 & 無 & コギリ & 定例活動 & 林内整備 & 外院F & 29 & 4.8 & 4.2 \\
\hline & & & & & & & もりもりB & 15 & 5.1 & \\
\hline & & & & & & & もりもりC & 28 & 4.6 & \\
\hline & & & & & & & もりもりD & 35 & 3.5 & \\
\hline & 作對タイ゚゚ & 聞代 & 無 & ノギリ・ナタ & イ゙や & & 交野B & 30 & 7.1 & 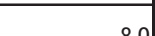 \\
\hline & 作羊タイJ & 間伐 & 無 & ノギリ & イベント & 里山講座 & もりもりA & 23 & 8.8 & 8.0 \\
\hline & & & & & & \begin{tabular}{|l} 
環境学習 \\
\end{tabular} & 外院A & 17 & 11.4 & \\
\hline & 作業タイプF & 間伐 & 無 & ノギリ & イベント & ·広場作以 & 外院D & 9 & 15.4 & 13.4 \\
\hline & 作對タイプa & 下莫州 & 全員 & 草杊に機 & 定例活動 & 林内整備 & $\begin{array}{l}\text { 里山B } \\
\end{array}$ & 32 & 0.7 & 06 \\
\hline & TF未メイン & 下早刚" & 使用 & 早对饭栈 & 足例沼坋 & 你人阷砽 & 里山C & 31 & 0.5 & 0.6 \\
\hline 定 & 作業タイプb & 下草刈り & 2台使用 & カマ·草刈り機 (2台) & 定例活動 & 林内整備 & 五月山B & 9 & 1.8 & 1.8 \\
\hline 常 & & & & & & & 泉南A & 20 & 2.4 & \\
\hline 管 & 作業タイプC & 下草刈り & 無 & 双 & 定例活動 & 林内整備 & 泉南B & 22 & 3.0 & 2.8 \\
\hline 理 & & & & & & & 泉南C & 37 & 3.1 & \\
\hline & 作業タイプd & 下草刈り & 無 & 加 & イベント & 下草刈りイベント & 五月山A & 23 & 1.2 & 1.2 \\
\hline & 作業タイプe & 下草刈り & $\begin{array}{lll}\text { 無 } \\
\end{array}$ & 双 & イベント & 里山講座 & 交野C & 5 & 2.5 & 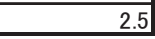 \\
\hline
\end{tabular}

表 -2 対象地点の管理作業後の植生状況等

\begin{tabular}{|c|c|c|c|c|c|c|c|}
\hline 団体名 & 場所 & $\begin{array}{c}\text { 作業面積 } \\
\left(\mathrm{m}^{2}\right)\end{array}$ & & 林相 & $\begin{array}{c}\text { 高木·亜高木の } \\
\text { 立木密度 } \\
\left(\text { 本/100 } \mathrm{m}^{2}\right)\end{array}$ & $\begin{array}{c}\text { 低木の立木密度 } \\
\left(\text { 本/100 } \mathrm{m}^{2}\right)\end{array}$ & 林床被度 \\
\hline \multirow{2}{*}{$\begin{array}{c}\text { 五月山 } \\
\text { グリーンエコー }\end{array}$} & 五月山A & 4978 & 落葉 & アベマキ、コナラ & 50 & 12 & 5 \\
\hline & 五月山B & 1145 & 混交 & コナラ、ヤマザクラ、アラカシ、アカマツ & 24 & 25 & 2 \\
\hline \multirow{3}{*}{$\begin{array}{l}\text { 交野里山 } \\
\text { ゆうゆう会 }\end{array}$} & 交野A & 3073 & 落葉 & コナラ•クヌギ・ヤマザクラ & 9 & 70 & 2 \\
\hline & 交野B & 1691 & 混交 & コナラ・アカマツ・ソヨゴ & 26 & 24 & 1 \\
\hline & 交野C & 525 & 落葉 & ソメイヨシノ & 10 & 3 & 5 \\
\hline \multirow{3}{*}{$\begin{array}{l}\text { 泉南の里山を } \\
\text { 大切にする会 }\end{array}$} & 泉南A & 757 & 混交 & ソヨゴ、ネジキ、クリ、コナラ & 32 & 16 & 1 \\
\hline & 泉南B & 604 & 常緑 & ソヨゴ、ネジキ & 66 & 45 & + \\
\hline & 泉南C & 896 & 常緑 & ヤマモモ、クロバイ & 22 & 15 & 2 \\
\hline \multirow{6}{*}{ 外院の森 } & 外院A & 568 & 混交 & ソヨゴ・アカマツ・ネジキ・リヨウブ & 27 & 35 & 1 \\
\hline & 外院B & 221 & 混交 & ヤマザクラ・ヤマモモ & 7 & 3 & + \\
\hline & 外院C & 169 & 常緑 & クロバイ・アカマツ & 20 & 14 & + \\
\hline & 外院D & 1490 & 常緑 & ヤマモモ & 31 & 3 & + \\
\hline & 外院E & 171 & 常緑 & ヤマモモ・ヒサカキ & 45 & 41 & + \\
\hline & 外院F & 420 & 落葉 & コナラ・ネジキ & 27 & 11 & + \\
\hline \multirow{4}{*}{ もりもりクラブ } & もりもりA & 1622 & 混交 & ヒサカキ・ヤマザクラ & 21 & 14 & + \\
\hline & もりもりB & 691 & 常緑 & ヒサカキ & 52 & 17 & + \\
\hline & もりもりC & 613 & 常緑 & ヒサカキ、ソヨゴ & 86 & 46 & + \\
\hline & もりもりD & 340 & 落葉 & ヤマザクラ、リヨウブ & 60 & 16 & 1 \\
\hline \multirow{3}{*}{ 里山俱楽部 } & 里山A & 4020 & - & - & 0 & 0 & 5 \\
\hline & 里山B & 19216 & 落葉 & クヌギ、コナラ & 47 & 31 & 4 \\
\hline & 里山C & 2784 & - & - & 0 & 0 & 5 \\
\hline
\end{tabular}

\section{3. 解析結果および考察}

（1）里山管理における作業タイプの分類

図 -1 に作業タイプの分類図を示す。

分類基準については, 本研究に抢ける各調査地点ごとの解析結 果より, 里山管理に抢ける作業効率が, 作業方法之活動目的によっ て初期管理, 定常管理別に作業効率が大幅に変動することから, 作業効率と関連性がみられた作業方法と活動の目的に着目して里 山管理作業の分類をまず行うこととした。

まず皆伐や間伐の初期管理や下草刈りの定常管理において, 機 械（チェーンソウや草刈り機）をどの程度使用したかで分け, 次 に活動の目的（定例活動, イベント）によって分類した。活動の 目的の中で, 定例活動とは各団体の正規の会員が定期的に行って いる里山管理活動のことで, イベントとは正規の会員が小学生の 環境学習や里山に関心を持っている市民のために里山講座等の一 環として里山管理活動を行ったもので, 会員以外の人も参加する
活動のことである。

さらに, 定例活動においては林内整備を目的とした管理作業と 広場作りを目的とした管理作業とに分け，イベント活動において は里山体験講座, 環境学習の一環としての管理作業と広場作り, 下草刚りに分類した。林内整備とは, 立木密度が密な林内におい て密度調節之樹木の生長促進を目的として, 主に常緑樹の伐採を 行い，伐採木を近くに集めるまでの一連の管理作業のことである。 広場作りとは里山管理活動を行うにあたり, 拠点となる場所や休 憩する場所, 遊び場となる場所を作るため, 立木密度がかなり疎 となるように間伐を行い, 伐採木を近くに集めるまでの作業のこ とであり，整地作業は含まれていない。

その結果，初期管理は作業内容が皆伐で作業方法が全員機械を 使用し, 活動目的が定例活動で林内整備を行った作業タイプ A ら，作業内容が間伐で機械を全く用いず，活動目的がイベントで 環境学習を兼㸚た広場作りである作業夕イプ Fまでの 6 タイプに 
分類できた。定常管理は作業方法が全員機械を使用し, 活動目的 が定例活動で林内整備を行った作業タイプ a から作業方法が機 械を全く用いず, 活動目的がイベントで里山講座の作業タイプ e の 5 タイプに分類できた。

\section{（2）作業タイプごとの作業効率}

以上の作業タイプごとに各地点ごとの作業効率を整理し, 各作 業タイプごとの作業効率の平均值を算出したものを表 -1 に, 調 查対象地点の管理作業後の植生状況等を表 -2 に示す。

初期管理をみると, 作業内容が間伐で機械を用いず, 環境学習 の一環として広場作りをイベントで行った作業タイプ F が 13.4 人 $/ 100 \mathrm{~m}^{2}$ ・日となり, 次いで, 作業内容と機械使用が同様で広 場作りを目的とした定例活動の作業タイプ C が 10.7 人 $/ 100 \mathrm{~m}^{2}$ ・ 日となり, 機械を使用しない広場作りはイベント, 定例活動にか かわらず多大な労力を要するといえる。

作業タイプ F の活動場所である外院 A は平均傾斜が 17 度で作 業面積が約 $568 \mathrm{~m}^{2}$, ソヨゴやネジキなどを中心とする林相で高木・ 亜高木の立木密度は 27 本 $/ 100 \mathrm{~m}^{2}$, 低木の立木密度は 35 本 $/ 100$ $\mathrm{m}^{2}$ で，林床の植生被度は 1 である。また同じく作業タイプ $\mathrm{F}$ の 活動場所である外院 D は平均傾斜が 9 度で作業面積が約 $1490 \mathrm{~m}^{2}$, ヤマモモを中心とする林相で高木・亜高木の立木密度は 31 本/ $100 \mathrm{~m}^{2}$, 低木の立木密度は 3 本 $/ 100 \mathrm{~m}^{2}$ で, 林床の植生被度は + で ある。

一方，皆伐，間伐にかかわらず定例活動で林内整備を目的とし た場合は，機械の使用の有無によって作業効率は大幅に異なり， 機械を使用した作業タイプ B が 2.0 人 $/ 100 \mathrm{~m}^{2}$ ・日となり，次い で, 作業タイプ A が 2.2 人 $/ 100 \mathrm{~m}^{2}$ ・日と作業効率の高い值を 示した。

作業タイプ B の活動場所で最も作業効率が高い五月山 B は, 平均傾斜が 9 度で作業面積は約 $1145 \mathrm{~m}^{2}$, コナラやアラカシなど を中心之する林相で高木・亜高木の立木密度は 24 本 $/ 100 \mathrm{~m}^{2}$, 低 木の立木密度は 25 本 $/ 100 \mathrm{~m}^{2}$ で, 林床の植生被度は 2 である。次 いで作業効率が高い五月山 A は平均傾斜が 23 度で作業面積は約 $4978 \mathrm{~m}^{2}$ ，アベマキやコナラなどを中心とする林相で高木・亜高木 の立木密度は 50 本 $/ 100 \mathrm{~m}^{2}$, 低木の立木密度は 12 本 $/ 100 \mathrm{~m}^{2}$ で, 林床の植生被度は 5 である。

また，市民参画型の活動では最む多用されている作業タイプ D は作業内容之活動目的が同様で機械使用が異なる作業タイプ B と比較すると, 機械を用いた作業タイプ B の約 2 倍の労力であ る 4.2 人 $/ 100 \mathrm{~m}^{2}$ ・日となっており, 機械使用の有無が労力に大き な差異を生じさせるといえる。また，作業夕イプ E や F の上う に学習目的を兼称た場合には, 当然の結果として作業効率が下が ることが確認できた。

次に定常管理をみると, 市民参画型の活動では今回のケースで は最む多用されている, 機械を使用せず, 定例活動で林内整備を 目的とした下草刚り作業である作業タイプ c が 2.8 人 $/ 100 \mathrm{~m}^{2}$ ・日 と一番作業効率が低い值となって抢り, 次いで同じく機械を使用 せず, 活動の目的が里山講座としてのイベントである作業夕イプ $\mathrm{e}$ が 2.5 人 $/ 100 \mathrm{~m}^{2}$ ・日となり, 機械を使用しない場合, 林内整備 を目的とした定例活動や里山講座を目的としたイベントにかかわ らず多大な労力を要するといえるが, 初期管理とは異なり学習目 的を兼ねたとしても作業効率があまり下がらない結果となった。

作業夕イプ c の活動場所で作業効率が最も低い泉南 C は, 平 均傾斜が 37 度で作業面積は約 $896 \mathrm{~m}^{2}$, ヤマモモやクロバイなど を中心とする林相で, 高木・亜高木の立木密度は 22 本 $/ 100 \mathrm{~m}^{2}$, 低木の立木密度は 15 本 $/ 100 \mathrm{~m}^{2}$ で, 林床の植生被度は 2 である。 次いで作業効率が低い泉南 B は, 平均傾斜が 22 度で作業面積は 約 $604 \mathrm{~m}^{2}$, ソヨゴやネジキなどを中心とする林相で高木・亜高木 の立木密度は 66 本 $/ 100 \mathrm{~m}^{2}$, 低木の立木密度は 45 本 $/ 100 \mathrm{~m}^{2}$ で,
林床の植生被度は+である。

一方，定例活動で林内整備を行った場合，機械の使用によって 大幅に作業効率が高くなり，全員使用した作業タイプ a は 0.6 人 $/ 100 \mathrm{~m}^{2}$ ・日， 2 台使用した作業タイプ b は 1.8 人 $/ 100 \mathrm{~m}^{2}$ ・日之 なり，機械の使用台数が作業効率に大きな影響を与える事が確認 できた。

作業タイプ a の活動場所で作業効率が最も高い里山 C は, 平 均傾斜が 31 度で作業面積が約 $2784 \mathrm{~m}^{2}$, 全伐跡地であるため立木 はなく, 林床の植生被度は 5 である。次いで作業効率が高い里山 B は, 平均傾斜が 32 度で作業面積が約 $19216 \mathrm{~m}^{2}$, クヌギやコナラ などを中心とする林相で高木・亜高木の立木密度は 47 本 $/ 100 \mathrm{~m}^{2}$, 低木の立木密度は 31 本 $/ 100 \mathrm{~m}^{2}$ で，林床の植生被度は 4 である。

また，イベント活動を比較すると，どちらあ機械を用いていな いにあかかわらず, 下草刚りイベントの作業効率は 1.2 人 $/ 100 \mathrm{~m}^{2}$ ・ 日であり, 里山講座の 2.5 人 $/ 100 \mathrm{~m}^{2}$ ・日の約倍となっており, 学 習を目的とするイベントでは作業効率が大きく低下することが明 らかとなった。

\section{4. まとめ}

本研究を通じて得られた事項をまとめるとともに，残された今 後の課題を述べる。

(1) 初期管理と定常管理では当然大幅に必要となる労力が異な り，皆伐や間伐などの初期管理は多大な労力が必要となる ことが明らかとなった。

(2) 市民参画型の里山管理で多用されている初期管理では，機 械を一切使用せず定例活動によって林内整備を目的とした 間伐作業である作業タイプ Dで，作業効率は 4.2 人 $/ 100 \mathrm{~m}^{2}$ ・ 日であり，定常管理では，機械を一切使用せず定例活動に よって林内整備を目的とした下草刈り作業である作業夕イ プ c で，作業効率は 2.8 人 $/ 100 \mathrm{~m}^{2}$ ・日が目安となることが 示唆された。

(3) 初期管理・定常管理共に機械使用によって大幅に労力が削 減され，概敉作業効率が倍化し，初期管理では 2.0 人/100 $\mathrm{m}^{2}$ ・日，定常管理では 1.8 人 $/ 100 \mathrm{~m}^{2}$ ・日が目安になること や，環境学習や里山講座などの学習目的を兼㸚ると作業効 率が当然下がることが確認できた。

(4) 本研究で得られた作業効率は, 今後市民参画型で管理面積, 活動回数, イベント回数, 参加人数, 作業方法, 活動の目 的といった里山管理計画を企画・立案し，実行に移すプロ セスに拈いて，有用な指標となると考えられる。

(5)しかし, 今回得られた知見は, 21 地点の調査という限ら れたデー夕の中で得た，あくまであ扔打よその目安であっ て以下のような課題が残されている。すなわち，管理作業 前後の植生状況の変化を比較し植生状況の作業効率への影 響を明らかにすることや，管理作業場所の傾斜度，参加者 の管理技術の習得度等の要因と作業効率との関連性を明ら かにすることが残された課題と考えられる。

\section{引用・参考文献}

1）重松敏則（1989）：二次林のレクリエーション的活用に関す 万生態学的研究：造園雑誌 53(1), 16-23

2 ) 武内和彦・䳝谷いづみ・恒川篤史 [編］（2001）：里山の環 境学：東京大学出版会, 146-150

3 ）重松敏則（1991）：市民による里山の保全・管理：信山社サ イテック，41-43

4 ) 高橋武彦（1998）：花の生態と花修景・第 3 章：角川書店, 170-176 